Educational Research for Social Change (ERSC)

Volume 9 Special Issue June 2020

pp. 1-14

ersc.nmmu.ac.za

ISSN: 2221-4070

\title{
Learning How Language is Used in Higher Education to Strategically Marginalise Female, Queer, and Gender Non-Conforming People: An Autoethnographic Account ${ }^{1}$
}

Kudzaiishe Vanyoro

Kudzaiishe.vanyoro@wits.ac.za

Wits Centre for Diversity Studies, University of the Witwatersrand

\section{Abstract}

In this article, I examine how language informs the systemic and structural manner in which the university space not only marginalises, but also exploits female and gender nonconforming people. I base my account on my experiences in two universities in southern Africa-one in Zimbabwe and the other in South Africa. I aim to show how gender and sexuality borders can be permeated by gaining critical awareness of the working of power and privilege in language that normalises the oppression of one by the other. I do this through a reflective autoethnographic account of the temporal trajectories involved in my experience as an academic of gender and sexuality in universities. I explore the notion of university as a social site where power relations of privilege and marginality can be found to be vivid if not violent. I reflect on my positionality and complicity in exploitative power relations in the university. I also make use of \#FeesMustFall diaries as archival data to account for dynamics of exclusion. Theoretically, the article employs the colonial matrix of power to show how coloniality upholds gender and sexuality norms in universities and academics. The purpose of this paper is not to propose strategies for other institutions to use for unlearning pedagogies. Rather, the role of the paper is to document my and others' experiences of how heteropatriarchy manifests in the language used in the lecture room and beyond. In conclusion, the article shows how the author found critical diversity literacy, a learning pedagogy that promotes discomfort, helpful in realising the complicity of language in dominance.

Keywords: language, gender, sexuality, pedagogy of discomfort, critical diversity literacy, coloniality

Copyright: (C) 2020 Kudzaiishe Vanyoro

This is an open access article distributed under the terms of the Creative Commons Attribution NonCommercial License, which permits unrestricted non-commercial use, distribution, and reproduction in any medium, provided the original author and source are credited.

\footnotetext{
${ }^{1}$ Ethical clearance number: HRECNM 20-06-029
} 
Please reference as: Vanyoro, K. (2020). Learning How Language is Used in Higher Education to Strategically Marginalise Female, Queer, and Gender Non-Conforming People: An Autoethnographic Account. Educational Research for Social Change, 9(0), 1-14. http://dx.doi.org/10.17159/2221-4070/2020/v9i0a1

\section{Introduction}

The purpose of this article is not to propose strategies for other institutions to use for unlearning pedagogies. Rather, this article serves to highlight the finer details of how sexism and homophobia are entrenched through the language used by lecturers during teaching and learning in the classroom. It also seeks to add to documented individual experiences of misogynistic language in the lecture room. It does so by drawing on elaborate, autoethnographic observations made during learning at two southern African universities by a black, male, cisgender, and heterosexual person. The article examines the systemic and structural manner in which the university space can be a site of coloniality that not only marginalises but also exploits female and queer people. It departs from the observation that, while significant research has been carried out on gender (Barnes, 2007; Bennet, 2002; Gaidzanwa, 2000; Mama, 2003; Ndhlovu \& Masuku, 2004; Okeke, 2003; Otunga \& Ojwang, 2003; Pereira, 2007; Zindi, 1994) and sexuality (Francis \& Msibi, 2011; Kiguwa \& Langa, 2017; Msibi, 2009, 2013) in African universities, there is a paucity of reflective literature on heterosexual men's experiences of gender and sexuality in these spaces-in what Msibi $(2013$, p. 1) called the "the silencing of queer issues in higher education." While they dealt with coloniality as a system implicit in epistemic injustices, scholars (Almeida \& Kumalo, 2018; Ndlovu-Gatsheni, 2013; Mpofu, 2013) barely accounted for how it informs the gender and sexuality-based oppressions that take place in the university as a result of the hierarchisation that coloniality enforces. Meanwhile, those scholars who deal with gender and sexuality relations in the university (Barnes, 2007; Bennet, 2002; Francis \& Msibi, 2011; Gaidzanwa, 2000; Kiguwa \& Langa, 2017; Mama, 2003; Msibi, 2009, 2013; Ndhlovu \& Masuku, 2004; Okeke, 2003; Otunga \& Ojwang, 2003; Pereira, 2007 ; Zindi, 1994) lack an autoethnographic voice from the men who are agents of gender and sexuality-based discrimination.

Lastly, previous research on the topic has rarely grappled with how the colonial matrix of power enforces colonially established exclusion of women and queer people in the university. A colonial matrix of power heuristic (Mignolo, 2008) allows one to read intersecting race, class, gender, and sexuality power relations in the university. The colonial matrix of power operates through control of the economy, control of authority, control of gender and sexuality, and control of knowledge and subjectivity (Mignolo, 2008). This article, therefore, shows how "domination is not just economic, but it operates at all levels of interrelation between the different domains of the colonial matrix of power" (Mignolo, 2008, p. 15). The colonial matrix of power speaks to all forms of domination and considers them products of white European Christians' classificatory system that ranked human beings differently (Mignolo, 2008). During the conquest of Africa, white men positioned themselves as the greatest standard of human. Women and children became the template for the description of the inferiority of non-Europeans (Mignolo, 2008). Hence, to be a woman or a man who is feminine in a space such as a university that was originally structured and systematised for the sons of Empire, not sons and daughters of black people and former slaves, is punitive. That said, the article also shows how the author found critical diversity literacy (CDL), a discomfort promoting pedagogy, helpful to understand the complicity of language in dominance.

\section{Methodological Considerations}

The data in this paper can be divided into two sections. The first data set is based on my personal diary and autoethnographic reflections of learning at a Zimbabwean university. The second data set is based 
on my experience at a South African university and from accounts from an anthology by fallists ${ }^{2}$ entitled, Rioting and Writing: Diaries of Wits Fallists (Chinguno et al., 2017). The latter became important as supporting evidence of the university's gender and sexuality politics because \#FeesMustFall was an exhibition of problems affecting students and staff in the university. I was not actively involved in the \#FeesMustFall movement; hence, I used the accounts of these fallists as archival data to support my argument. The book is probably one of the most comprehensive anthologies of experiences by university students who participated in the \#FeesMustFall movements. Their stories help to elucidate experiences of black, female, and queer students because all the book contributors have experienced or were associated with the \# FeesMustFall movement in 2015-2016.

In this article, I reflect on my experiences and the observations of life and society that I made in the university space. The use of the autoethnographic data in the paper, however, raises methodological questions as to how one can use experiences from different physical and temporal spaces to (re)think understandings of (un)learning in another space. However, this way of "performing autoethnography" draws from Spry's (2001, p. 709) recommended "process of integrating the 'doing' of autoethnography with critical reflection upon autoethnography as a methodological praxis." This approach understands that the body is a politically inscribed site of meaning making (Alexander, 2000; Spry, 2001). "Informed by recent work in autobiography, autoethnographic methods recognise the reflections and refractions of multiple selves in contexts that arguably transform the authorial ' $l$ ' to an existential 'we'" (Spry, 2001, p. 711). Hence, there is potential in autoethnographic accounts from other disciplines and spaces to provide multiple accounts through which people from different locations can use to identify with, and empathise with, others. "In autoethnographic methods, the researcher is the epistemological and ontological nexus upon which the research process turns" (Spry, 2001, p. 711). The ethnographic accounts I make use of in this article also allow me to disrupt bordered thinking to understand challenges faced in various higher education institutions in Southern Africa as different but similar in their genealogy.

Bainbridge (2007, p. 9) argued that indigenous researchers can employ an "epistemology of insiderness" to construct and theorise knowledge where one assimilates their life and understandings into the research. The "inward gaze" adopted in autoethnography (Bainbridge, 2007, p. 8) is a way through which researchers can create the self who has crossed and lived between borders (Neumann, 1996). That self is the present writer, seeking to use my experiences to help readers understand personal and collective complicity (if any) in the university's power relations. In the following quote, Bainbridge noted how as a "complete insider" she was able to perform autoethnography: "I interrogated my connection to the research phenomenon by writing memories of my life story, which allowed engagement with the research phenomenon on both an experiential and intellectual level" $(2007$, p. 9). The contact between the experiential and intellectual is, therefore, an opportunity for the production of different praxis tools.

\section{Rooting Heteropatriarchy in Neoliberalism and Coloniality}

This section shows how heteropatriarchy is rooted in coloniality and neoliberalism. Neoliberalism is a system that is "hostile to any kind of progressive social redistribution, that is to say, distribution in favour of the popular classes" (de Sousa Santos, 2017, p. 243). Neoliberalism promotes individualism, which leads to the exponential growth of inequality. For scholars like Maldonado-Torres:

\footnotetext{
2 The name "fallist" was used to refer to activists who took part in the \#FeesMustFall protests.
} 
Generally speaking, liberal societies, including universities and their liberal arts and sciences, strive to create a world to the measure of ambiguous and incomplete legal changes that perpetually postpone, if not seek to eliminate, any serious accountability, justice, and reparations. (2016, p. 4)

The university can, therefore, be thought of as a neoliberal space because it abides by the free-market model that commodifies education and stresses individual capabilities as key to attaining recognition. Neoliberalism can be considered an outcome of coloniality. Coloniality refers to structures and systems that outlive the end of formalised colonialism (Maldonado-Torres, 2007). Coloniality is the domination that remains long after the end of the formalised political domination of Western Europe over its formerly colonised (Quijano, 2007). According to Grosfoguel, we still live under the same "colonial power matrix" and through juridical-political decolonisation, former colonies were simply brought from a period of "global colonialism" to the current period of "global coloniality" (2007, p. 219). It is this global coloniality that is embodied in many present institutions of higher learning, worldwide. The university in the Global South in particular, noted Grosfoguel (2007), remains not a university of the Global South but a Westernised university in the Global South. In a way, the university in Zimbabwe and South Africa might be different institutions in different countries, but they are both subject to learning discourses shaped by neoliberalism and coloniality.

It can be argued that coloniality is also a highly heteropatriarchal system. This was seen in how decolonial movements such as \#FeesMustFall and its agitation to decolonise the university in South Africa spoke to something much more than the financial politics that the face value of the hashtag suggests. Apart from it being a call for free education for black students, \#FeesMustFall was also a struggle against heteropatriarchy and cisnormativity in South African universities. In Rioting and Writing: Diaries of Wits Fallists, activists Crispen Chinguno et al. defined decolonisation as "The rejection of white supremacy and heteropatriarchal order along with other forms of prejudice that characterise the ongoing colonial project, as well as the quest to redress the socio-economic, political and spiritual depredations of colonial history" (2017, p. 18). Consequently, they also defined a fallist as someone who defies the heteropatriarchal order (Chinguno et al., 2017). This is because the university in Latin America and Africa, as a structure and system of power and knowledge, retains coloniality and the tendency to produce victims in the shape of powerless and marginal peoples (Grosfoguel, 2007). Decolonisation in South African universities and beyond need not be thought of as just being about race and class, but also about the gender and sexuality censures that the university facilitates.

The South African university is a historically white university, based on the Bantu Education Act of 1953. This apartheid act was designed to exclude black people from the white education system. The Act also led to the institutionalisation of historically black universities (HBUs; Almeida \& Kumalo, 2018) such as the university currently known as Fort Hare. All these factors make the South African university Westernised by design. "The power dynamics inherent in the knowledge productions system within the westernized university allow for people and voices of whiteness to be legitimized while people and voices of indigenous scholars continue to be marginalized" (Almeida \& Kumalo, 2018, p. 6). These authors saw the black person's role in the Westernised university as often that of apprentice (Almeida \& Kumalo, 2018). Using an intersectional lens, I call for a much more nuanced definition of the term "black person." This is because a black person is not only black but is also black and gendered or sexualised. These other identity markers coconstitute the facticity of blackness that leads to dismemberment. Hence, Robert Kriger (2016) wrote of how universities in South Africa were founded by colonialists for the education of the sons of Empire, not black people or women and other marginal peoples who were considered disposable during and, indeed, after apartheid. For the latter, the university space is a punitive site of coloniality. 
This article, therefore, considers those intersecting problems that coloniality and neoliberalism have established in universities located in both Zimbabwe and South Africa. Here, I provide a brief background of coloniality and neoliberalism's influence in the Zimbabwean higher education (HE) landscape. The funding mechanism of the current education system in Zimbabwe is shaped by the economic structural adjustment programme (ESAP) adopted from 1991 to 1995 after the government finally conceded that socialist orientation was not a viable option in Zimbabwe (Zvobgo, 2003). Under pressure from the International Monetary Fund and the World Bank, the government had agreed to strengthen the economy along the free-market route (Zvobgo, 2003). Through ESAP, international finance organisations, supported by their funders such as Britain and the United States of America, dictated a complete reform of the government's economic policies (Zvobgo, 2003). This move marked the neoliberalisation of the Zimbabwean economy, including the education system, by calling on every Zimbabwean to bear the cost of education. ESAP stated that all educational institutions would institute cost-recovery measures to reduce the financial burden created by increasing costs (ESAP, 1991 cited in Weaving, 2019).

That said, the introduction of other state universities in Zimbabwe to complement the University of Zimbabwe, which was established during Rhodesia, significantly marked the rise in neoliberal marketdriven degree-granting institutions along with a massive commodification of education in Zimbabwe. This is because the degrees offered at these institutions, which include the Midlands State University, the National University of Science and Technology, and Great Zimbabwe University, were specifically tailored to link with the demand for skills in the labour market. The emergence of these universities was also accompanied by a shift from state-assisted education, characterised by the provision of student grants and subsidised student accommodation, to capitalist-driven fees that left many students out of university or in debt. It suffices to say Zimbabwean universities "went from producing knowledge and professionals for the market to becoming ... a market of tertiary education ... being run like a market organization, a business organization" (Santos, 2012, p. 4). The new universities marked the introduction of degrees different to the University of Zimbabwe's Bachelor of Arts programmes in what can be read as a shift from the social relevance of the university to a market needs-based approach (Santos, 2012). News of the profitability of universities led to a government-led expansion of universities such that by 2004, Zimbabwe boasted over 13 universities with more the pipeline (Ndhlovu \& Masuku, 2004). Due to their market value, most of these universities' institutional educational programmes are not rooted in transformation. Rather, they support the heteropatriarchal capitalist system present in the neoliberal policies and institutions within which they are rooted.

Many African feminist thinkers like Mama (2003) have argued that colonialism was a gendered project, and it can also be argued that the neoliberalisation of universities through ESAPs in Zimbabwe reinforced heteronormativity in $\mathrm{HE}$ institutions. This is because the neoliberalisation of education in Zimbabwe led to the further entrenchment of the "dog-eat-dog" mentality among students as excellence and affordance defined who was able to obtain value for money from the university. Neoliberalism is a form of coloniality that brought to Africa the idea that learning is a combative and aggressive process (Barnes, 2007). This competition is also highly gendered. Barnes (2007) posited that African universities are marked with codes that define men as thinkers, aggressive debaters, athletes, and boys becoming men. As an educational space that is characterised by hegemonic neoliberal and heteropatriarchal learning discourses, the university in Africa (Ndlovu-Gatsheni, 2013) has largely been constituted as a site of formation of transnational elites - who have, for the most, part justified and continuously elaborated coloniality as a global organising principle (Suarez-Krabbe, 2012). There is now a vicious exercise of dominant masculinity in academia that made the institutional culture of the university in Africa (Mama, 2003; Ndlovu-Gatsheni, 2013) "of the new-men for the new-men" (Barnes, 2007 , p. 12). Therefore, to be a cisgender, heterosexual man in these institutions means being a signatory to the oppression of the weaker women, men, or queer people. 


\section{Theoretical Considerations: Why Gender and Sexuality Matter}

This section shows the relationship between gender and sexuality and why they matter in neoliberal institutions. Sex and gender are imbricated in one another in identity politics. Sex consists of physical organs such as the male organ (penis), the female organ (vagina) or ambiguous organs (intersex). These sexual organs are used to socially assign specific roles and attributes to different bodies at birth. The assignment of roles based on one's surface sex biological configuration is called gendering. Butler (1986, p. 35) "underst[ood] sex to be the invariant, anatomically distinct, and factic aspects of the female body, whereas gender, is the cultural meaning and form that that body acquires." The distinction between male and female serves as a basic organising principle for every human culture (Bem, 1981). By being reliant on the binaries of male/female, strong/weak, intelligent/dumb, academic institutions are guided by tacit assumptions of masculinity and femininity (Gaidzanwa, 2000). Barnes $(2007$, p. 8) described how the colonial association of masculinity with the labour of the mind, and femininity with the labour of the body, was transmitted into the university in Africa, "along with the senates, the vice-chancellors, the graduation robes, the funny flat hats and the rituals of examination." Therefore, because today's social organising principle is based on gender, the neoliberal university has conformed to the same protocol.

Scholars like Thabo Msibi have written on how queer people experience the South African university, arguing that "South Africa is still very much a patriarchal society, with ideas around manhood still deeply entrenched" (2009, p. 51). Msibi (2009) posited that apart from being a gendered environment, the university in Africa is also hostile towards non-heterosexual identities. Recent research conducted in South Africa has shown that university residences remain one of the most homophobic spaces, deeply entrenched in heteronormative cultures that exclude queer students (Jagessar \& Msibi, 2015; Kiguwa \& Langa, 2017). Bennet (2002) suggested that the higher education environment in Africa is a site for the performance of heterosexuality as a major route into resources, stability, identity, and citizenship. Because heterosexuality is privileged in the university, gender non-conforming people are ostracised or punished. Francis and Msibi (2011, p. 159) posited that "societal and organizational institutions are designed to award privileges and benefits to members of the dominant group (heterosexuals) at the expense of members of the subordinated group (GLB)." All these factors inform the oppression of queer people who are marginalised in the university by their failure to conform.

In the next section, I show how I experienced the use of language that sought to epistemically discipline women in the classroom. I then analyse how language can be used to sexually harass students in universities. This will be used to show how heterosexuality is normalised as the legitimate sexuality in the university. Through support of evidence from \#FeesMustFall (FMF) movements, the section will also show students' experience of homophobia and sexism in the institution.

\section{Between 2014 and 2020: Brief Reflections on Zimbabwean and South African Lecture Room Dynamics}

This section reflects on two incidences that took place in the lecture rooms of two universities, one in Zimbabwe and the other in South Africa. Between 2012 and 2015, I was studying towards an honours degree in Zimbabwe and, in 2013, I joined a South African university as an exchange student for a semester of studying human rights. In 2018, I returned to South Africa as a master's student majoring in critical diversity studies (CDS). In some sections of my discussion, I refer to my student diary notes from Zimbabwe in 2014 and, in some instances, I rely on my memory to reflect on what happened. In some cases, I refer to media reports of certain issues to support my thoughts. While more experiences could have been mentioned in this section, I believe the two experiences mentioned here will help flesh out the similarities between two universities located in different countries. 


\section{March 2014 (Zimbabwean University)}

The university campus that I attend in Zimbabwe is located in a high-density suburb. The campus is small but densely populated. At this campus, there are barely any student protests due to the proximity of a military base to the campus. These spatial arrangements confirm Maldonado-Torres' (2016) assertion that universities can be centres of command and control, which make them easy to militarise when opposition rises. My first impression of the campus is as follows:

Oppression and Space! The administration block is the first thing you see when you enter the campus. One sees the Zimbabwean national flag and the university flag, symbols of phallic state power. The campus is built next to a military base, further into a "ghetto" where students who are off campus stay. Although the military is never present on campus, rumours of their wrath spread viciously. This makes it hard for people with various struggles to protest on campus. (Personal diary, 2014)

Most of the buildings are old, bearing witness to the colonial British style that the builders used. This is typical of most universities in Zimbabwe, which inherited structures built during colonialism. The lecture I attend during this particular week is an introduction to media course. The lecturer is a black male who likes to crack jokes. His name is $\mathrm{Mr}$ Matambo $^{3}$ and he always talks about his wife and children. At this particular point in my life, I barely think about his sexuality. For me, sexuality is rigidly heterosexual and there is no other way of looking at it.

Looking back to that day, I realise that the control of gender and sexuality, which uses the bourgeois secular family as a model and standard for the universalisation of heterosexuality (Mignolo, 2012), had a significant impact on my identity. I had come to know heterosexual marriage as the only legitimate social and sexual union.

Out of nowhere, he cracks a joke in class! The joke is about Matambo's sexual prowess. He hails from a clan whose totem is Soko Mukanya [monkey] an animal which is fondly known Makwira-miti [Kukwira meaning to climb to the top. Miti means trees]. During the lecture, as several other male lecturers pass through the lecture room to access their offices, one greets him saying "maswera sei makwiramiti? [How are you makwiramiti?]" This scene plays out as an endorsement of makwiramiti's identity. Matambo goes further and speaks of how he is not only good at climbing to the top of trees (like the monkey), but also of how he is also good in bed. He further alludes to the fact that he is also good at "kukwira [fucking] knowledge." Kukwira (in makwiramiti) is a slang word for being on top of a woman. Several classmates and I burst into tears of laughter! It does not once occur to me that this lecturer is being sexist or misogynistic. Yet at this moment, the lecturer and his colleagues have just strategically employed analogies that speak to the African idea of totems to objectify women in the classroom. Later that day, I have a conversation with other senior students about the lecture and I am told that this is how Matambo conducts his classes. Throughout that semester, Matambo makes misogynistic jokes and examples without disciplinary consequences from the university. Matambo is never charged for any form of sexual harassment by the university. If anything, his behavior is normalised as part of institutional teaching culture.

There are many reasons why male toxicity goes unpunished at universities. One could be that neoliberalism emphasises individualism making any lecturer's conduct pass because we think "this is just their character, as long as they don't kill or touch anyone it is okay." This is despite the fact that rape and harassment begin as a language before becoming physical. While the language used by

\footnotetext{
${ }^{3} \mathrm{Mr}$ Matambo is a pseudonym.
} 
Matambo in the lecture room may sound innocent, particularly to the complicit male students, it has dire consequences. To elucidate, at Zimbabwean universities, we call ourselves the University Bachelors Association (UBA) while female students are called University Spinsters Association (USA). These names already picture the heterosexual normative family which both male and female students are expected to embody. These names also create a binary of fixed male and female heterosexuality that epistemically erases gender non-conforming and homosexual identities. The control of gender and sexuality that uses the bourgeois secular family as a model and standard for the universalisation of heterosexuality (Mignolo, 2012), is at the core of this hegemonic project. The titles UBA and USA, therefore, endorse compulsory heterosexuality. When they coined the term compulsory heterosexuality, "lesbian feminists emphasized heterosexuality as an institutionalized part of the social order that fashions a world of gender binarism and hierarchy" (Seidman, 2009, p. 18). By the time I started engaging in relationships at university, I knew, without being told by anyone, that it had to be with a woman. This experience is also linked to findings in Hamlall's (2018) research on heterosexuality among men at a HE learning institution in KwaZulu-Natal where he found that "romantic relationships with girls, deriding homosexuality, and fear of being perceived as gay served as a means of establishing the young men's heteronormativity and created boundaries of social distance between themselves and homosexuals" (2018, p. 312).

At the Zimbabwean university, these discourses and attitudes do not end in the lecture room but also trickle down to the halls of residence, including the suburbs where students who fail to secure campus accommodation stay. Life in these suburbs, in one of which I stay at the time, often involves cohabiting with permanent residents who become students' landlords. In 2014, I note the following:

This is Marange, ${ }^{4}$ a students' residence ghetto. For some who are not as privileged enough to pay full fees at once to stay at campus residences, this community is an orientation to adulthood. Most cases of rape and misogyny among students go unpunished here. I think Marange is a diverse community that privileges the survival of men at the expense of the safety of women. The women fondly known as "USAs" (University Spinsters Association) are blamed for everything especially the high levels of sex in the community. (Personal diary, 2014)

In fact, the media portray female students who live in such suburbs negatively. For example, the Midlands State University (MSU) located in Gweru is often in the news regarding the behaviour of its students. In an article I come across in the Southern Eye titled, "MSU Students' Woes Boon for Landlords," the journalist stated that:

High levels of immorality associated with the university have seen locals christening the institution More Sex University which has harmed children growing up in this community. ... A woman of Senga says she has never allowed MSU students to stay in her home to keep her children and husband at a safe distance from the "immoral students." "If you give them half a chance, they will take your husband just to avoid paying rentals or to make a quick dollar for goodies and clothes, so I stay away from them as much as I can," she said. (Mhlanga, 2013, n.p.)

This newspaper article demonstrates the portrayal of female students as infidels by residents and the media. MSU female students are constructed as loose in the university, even in the afore-cited newspaper article in which they are depicted as "whores" who sell their bodies for monetary favours. Even male students actively construct this negative representation by referring to MSU female students as loose. This is why MSU is "affectionately" known as "More Sex University," a space where

\footnotetext{
${ }^{4}$ Pseudonym for one of the high density residential areas that house university students.
} 
one is "bound" to meet loose women. There is no denying the fact that some MSU female students do engage in transactional sex with multiple partners. However, my analysis considers this sex exploitation. Although describing slavery, Campbell and Elbourne (2014) captured the intersection of sex and slavery. For them, there are ties between slavery, the control of sexuality (including a slave's lack of self-ownership and the corresponding obligation to provide sexual labour), and perceptions of honour and dishonour. When these women are involved in transactional sex, the sex that is remunerated for becomes labour. The "obligation to provide sexual labour is rape" (Gqola, 2015, p. 40 ) because sex for monetary gain or in return for marks, presents them with constrained choices. The high financial demands of $\mathrm{HE}$ institutions, and the expectation that if you do not please a male lecturer you will fail, mediate institutionalised rape.

\section{December 2019 (South African University)}

Years later, at a South African university, a similar scenario to Mr Matambo's incident also plays out. The only difference is I am not there to witness it. One morning, I receive news of a male professor who is accused of using an inappropriate sexual example in class. The lecturer equated the length of an academic literature review to a woman's skirt that "should be short enough to attract attention, but long enough to cover the subject matter." The same lecturer is also accused of breaching reasonable professional boundaries through evidence brought forward by a female student that she was undergoing some personal difficulties and he tried to comfort her by commenting about her beauty. Although the lecturer is later found guilty of sexual harassment by the gender committee of the university, he is reinstated (Fengu, 2020, n.p.)

Commenting on how the statements made by witnesses on this case reveal the tolerance of sexual harassment within a university department, a report stated that:

Their testimonies depicted a school with a patriarchal culture, where invisible power is concentrated in the hands of men who are senior in academic ranks and constitute an 'Old Boys Club' or network," the ruling reads, adding that "the handful of women who had managed to rise in academic rank appeared to adopt or at least tolerate the status quo. The toxicity of that power lies in its lack of appreciation by those who have it . . . and their blindness to sexism and sexist behaviour confers privilege. (Fengu, 2020, n.p.)

This example shows why it is difficult to eradicate sexual harassment in $\mathrm{HE}$ institutions. Innocent as the comments made by the lecturer may appear, they objectify women. Gqola $(2015$, p. 39) opined that "part of violent gender power is in celebrating attributes associated with the masculine and ordering the world in terms of opposites, or binaries." The male lecturer assumes a form of hegemonic masculinity that enables him to use the female body as an example of anything-with little to no consequences from the institution. The lecturer's institutional authority is disguised as a scholarly authority (Santos, 2012). This scholarly authority is, of course, phallic and heteropatriarchal. This professor uses the woman's body as a sexualised example of how to write a literature review. It can be argued that this language is rapey because it subtly implies that women should be attractive to men, but still behave within accepted social norms. It also implies that if they do not, they deserve whatever happens to them. Therefore, sex jokes such as these are used to conceal the masculine and patriarchal, the systemic and structural, and to control the behaviour of women and other gender nonconforming people (Gqola, 2015). To elucidate, Gqola (2015) reminded us of how in South African colonies such as the Cape, slavocratic society created the stereotype of black women's hypersexuality to authorise and justify the institutionalised rape of women. By language or by force, women are systematically and structurally raped in such lecture rooms. 
Issues of sexual harassment and homophobia are also raised during \#FeesMustFall (FMF). According to Chinguno et al. (2017, p. 17), "The FMF movement further raised questions on racial identity, social class, positionality, gender, sexuality, the hetero-patriarchal order and the significance of an intersectional paradigm on how to 'do' and understand popular struggles and resistance." The shared experience of both the Zimbabwean and South African university is that, while both black men and women students are "at the bottom of the food chain," women are more vulnerable in both institutions. Andile Mthombeni wrote that, at Wits, "I was very much aware of the class, gender, sexuality and racial divide that exists within the campus" (2017, p. 50). While it was part of some sectors of the Wits FMF movement's goals to achieve gender and sexuality equality, the movement itself demonstrated how deeply engraved heteropatriarchy is among cis/hetero men on campus. Sello Mashibini wrote that "men sought to dominate the space and take credit for all the work that women were doing. They said it was time to confront the stereotypes that men are better leaders than women" (2017, p. 42). Simamkhele Dlakavu described how men dominated the space while women and queer men had to make food for the protestors. She also witnessed that questions such as "When is the food coming?" and "Why is the food so dry?" were made by the cis-het "men of our movement" (Dlakavu et al., 2017, p. 110). Hence, language was also used to organise how women conducted themselves in the university during FMF. In the next section, I discuss my journey in realising the need to unlearn deeply ingrained misogyny and homophobia through the adaptation of a new CDL vocabulary.

\section{January 2018-2020: Reconsidering "Fixed" Meanings of Gender and Sexuality Through CDL and Pedagogy of Discomfort}

During my master's, I was introduced to the reading practice of CDL. CDL made me aware that what often happens in universities is violent. It also equipped me to be able to read instances of violence at both the Zimbabwean and South African university. This is because CDL allows one to read prevailing social relations as one would a text (Steyn, 2015). Instead of "celebrating" or "tolerating" diversity as neoliberal learning models do, CDL is committed to uncovering "assumptions that obscure more penetrating understandings of historical and current social realities" (Steyn, 2015, p. 381). These assumptions include the essentialisation of womanhood and queerness. Through CDL, I realised that power determines which differences make a difference (Hall, 2007; Steyn, 2015). CDL is a reading practice initiated by Steyn (2015) and one of its 10 criteria was central in my journey to embracing queer and feminine presenting people and other differences. The criterion is "the possession of diversity grammar and vocabulary that facilitates a discussion of privilege and oppression" (Steyn, 2015, p. 385).

I found that this criterion intersects with the pedagogy of discomfort. The pedagogy of discomfort outlined by Zembylas and Boler (2003) is an educational approach towards the comprehension of norms and differences by having those conversations that render one uncomfortable. CDL is a pedagogy of discomfort because it requires personal reflection on one's own positionality and complicity in domination. While CDL helped me develop a vocabulary to name privilege and oppression, it also allowed me to observe my emotional reactions and responses to difference, begin to see unconscious privileges, and the invisible ways through which I comply with the dominant ideology (Zembylas \& Boler, 2003). An example is how during my first CDS classes I began to notice my agitation at my female classmates who called out patriarchy. Later, I realised how this agitation revealed my investment in male domination of women. This process also evoked emotional responses such as feelings of anger, grief, disappointment, and resistance (Zembylas \& Boler, 2003).

Through further engagement with classmates on the reason why my positionality led to the oppression of women in the space, I was able to call myself out. The vocabulary to name systems such as heteronormativity and cisnormativity was empowering for this process. These concepts exposed the 
historical power relations that underpinned my normalisation of heterosexuality and gender conformity. In the core CDS course we were given readings such as De La Torre's (1999) article "Beyond Machismo: A Cuban Case Study" that showed how in Cuban machismo, it is the cojones [testicles], not the penis, that are the cultural "signifier of signifiers" in male domination. The reading of such articles was followed by writing a reflective response paper that would be discussed openly in class. During the discussions, all views and personal stories were allowed, and this led me to listen to others who occupy a more vulnerable positionality than mine. I began to understand that power was at the fore of my positionality, which was laden with gender privilege(s). In the process, I was capacitated enough to name and critique systems such as "cisgender," "heteronormativity," "heteropatriarchy," "toxic masculinity," and so forth. With time, I began to reevaluate my worldviews. CDS course readings evaluated social movements such as FMF and \#MenAreTrash with open discussions on why these movements matter. Initially, my critique to \#MenAreTrash was the thought, "But it isn't all men that rape or beat up women!" However, through such open discussions, I learnt that this movement was necessary because all men are complicit in the violation of women by virtue of being born into that gender.

Today, I imagine how the situation in the Zimbabwean lecture room would have played out differently if Mr Matambo had gone through the same CDL course that I did. I also wonder if any lecturer would make inappropriate examples in class if universities made it compulsory for lecturers to go through gender sensitivity workshops and uncomfortable conversations on rape and sexual harassment. Would some of the hypermasculine male leaders of FMF have handled women and queer people differently if they had been made to understand gender and sexuality differently in their lecture rooms? The answer to these questions is that we will never know. However, at least both universities would be able to attest to the fact that something was being done to make cis-heteronormative men conscious of gender and sexuality differences on campus.

\section{Thinking of a Way Forward}

In this article, I have provided a concise context of the impacts of coloniality and neoliberalism on the gender and sexuality imperatives in universities, concretising them through a brief reflective narrative of the use of language in my learning experiences in Zimbabwean and South African universities. Through an outline of the colonial matrix of power, the article has shown how global colonial and neoliberal power relations shape current gender and sexuality trends in the university. By acknowledging that heteronormative and cisnormative individuals and communities are implicated in the exclusion of women and queer people, I have also shown how CDL as a pedagogy of discomfort informed my learning and unlearning in the space I currently find myself.

The purpose of this paper has not been to propose strategies for other institutions to use for unlearning pedagogies. Rather, the role of the paper has been to document my and others' experiences to show how heteropatriarchy manifests in the lecture room and beyond it. By referring to the two examples of male lecturers who normalised misogyny, the article hopes to show how that which is considered innocuous can become toxic. While the normative role of academic articles is to produce strategies, measures, and pedagogies for institutions to use, this paper has a different aim and conclusion. If anything, this article is pessimistic about the grand potentials of pedagogies of discomfort for institutional transformation. It, rather, points towards the individual commitment required for pedagogies such as CDL to be able to inspire individual changes. By dealing with gender and sexual norms as individuals, activists and lecturers can seek to educate individuals who form part of bigger institutions. This is a great starting point. From here moving forward, I think there is more work needed in the shape of autoethnographic or reflective articles that document how heterosexual men experience heteronormativity and cisnormativity in $\mathrm{HE}$ institutions in southern Africa. 


\section{References}

Alexander, B. K. (2000). Skin flint (or, the garbage man's kid): A generative autobiographical performance based on Tami Spry's tattoo stories. Text and Performance Quarterly, 20(1), 97-114.

Almeida, S., \& Kumalo, S. H. (2018). (De)coloniality through indigeneity: Deconstructing calls to decolonise in the South African and Canadian university contexts. Education as Change, 22(1), 124.

Bainbridge, R. (2007). Autoethnography in Indigenous research contexts: The value of inner knowing. Journal of Australian Indigenous Issues, 10(2), 1-16.

https://www.researchgate.net/profile/Roxanne Bainbridge/publication/236588448 Autoethnog raphy in Indigenous research contexts The value of inner knowing/links/02e7e53c5f939af1 c2000000/Autoethnography-in-Indigenous-research-contexts-The-value-of-inner-knowing.pdf

Barnes, T. (2007). Politics of the mind and body: Gender and institutional culture in African universities. Feminist Africa, 8(1), 8-25.

Bennett, J. (2002). Exploration of a gap: Strategising gender equity in African universities. Feminist Africa 1: Intellectual Politics, 34-63.

Bem, S. L. (1981). Gender schema theory: A cognitive account of sex typing. Psychological Review, 88(4), 354.

Butler, J. (1986). Sex and gender in Simone de Beauvoir's Second Sex. Yale French Studies, 72, 35-49.

Campbell, G., \& Elbourne, E. (Eds.). (2014). Sex, power, and slavery. Ohio University Press.

Chinguno, C., Kgoroba, M., Mashibini, S., Masilela, B. N., Maubane, B., Moyo, N., Mthombeni, A., \& Ndlovu, H. (Eds.). (2017). Rioting and writing: Diaries of Wits fallists. https://docs.wixstatic.com/ugd/de7bea 8ff05c74ed634e1fbf3d179284f74cd6.pdf

De Sousa Santos, B. (2017). The resilience of abyssal exclusions in our societies: Toward a post-abyssal law. Tilburg Law Review, 22(1/2), 237-258.

De La Torre, M. A. (1999). Beyond machismo: A Cuban case study. Annual of the Society of Christian Ethics, 213-233.

Dlakavu, S., Ndelu, S., \& Matandela, M. (2017). Writing and rioting: Black womxn in the time of Fallism. Agenda, 31(3/4), 105-109.

Fengu, M. (2020, February 18). Wits' controversial decision to reinstate lecturer accused of sexual harassment. City Press. https://city-press.news24.com/News/wits-controversial-decision-toreinstate-lecturer-accused-of-sexual-harassment-20200218

Francis, D., \& Msibi, T. (2011). Teaching about heterosexism: Challenging homophobia in South Africa. Journal of LGBT Youth, 8(2), 157-173.

Gaidzanwa, R. (2000). Academic careers and women at the University of Zimbabwe [Paper presentation]. Conference on Gender Equity, Democracy and Human rights, University of Zimbabwe, Harare.

Gqola, P. D. (2015). Rape: A South African nightmare. Jacana.

Grosfoguel, R. (2007). The epistemic decolonial turn: Beyond political-economy paradigms. Cultural Studies, 21(2/3), 211-223.

Hall, S. (2007). Living with difference. Soundings, 37, 148-158.

Hamlall, V. (2018). Heterosexual relationships among young black men in the construction of masculinity at a South African university. Social Dynamics, 44(2), 306-321. 
Jagessar, V., \& Msibi, T. (2015). "It's not that bad": Homophobia in the residences of a university in KwaZulu-Natal, Durban, South Africa. Agenda, 29(1), 63-73.

Kiguwa, P., \& Langa, M. (2017). "So I decided not to invade straight black men's space": Exploring heteronormative spaces on campus. South African Journal of Higher Education, 31(4), 53-71.

Kriger, R. (2016, October 4). Shredding the veil of reconciliation. Litnet. www.litnet.co.za/shreddingveil-reconciliation

Maldonado-Torres, N. (2007). On the coloniality of being: Contributions to the development of a concept. Cultural Studies, 21(2/3), 240-270.

Maldonado-Torres, N. (2016). Outline of ten theses on coloniality and decoloniality. Fondation Franz Fanon. https://fondation-frantzfanon.com/outline-of-ten-theses-on-coloniality-anddecoloniality/

Mama, A. (2003). Restore, reform but do not transform: The gender politics of higher education in Africa. Journal of Higher Education in Africa, 1(1), 101-125.

Mashibini, S. (2017). University as a site of struggle: Contestation of ideas, space and leadership. In C. Chinguno, M. Kgoroba, S. Mashibini, B. N. Masilela, B. Maubane, N. Moyo, A. Mthombeni, \& H. Ndlovu (Eds.), Rioting and writing: Diaries of Wits fallists (pp. 39-43). https://docs.wixstatic.com/ugd/de7bea_8ff05c74ed634e1fbf3d179284f74cd6.pdf

Mhlanga, B. (2013, July 16). MSU students' woes boon for landlords. Southern Eye. https://www.southerneye.co.zw/2013/07/16/msu-students-woes-boon-for-landlords

Mignolo, W. D. (2008). Introduction: Coloniality of power and de-colonial thinking. Cultural Studies, 21(2/3), 155-167.

Mignolo, W. D. (2012). Local histories/global designs: Coloniality, subaltern knowledges, and border thinking. Princeton University Press.

Mpofu, W. J. (2013). Coloniality in the scramble for African knowledge: A decolonial political perspective. Africanus, 43(2), 105-117.

Msibi, T. (2009). Not crossing the line: Masculinities and homophobic violence in South Africa. Agenda, 23(80), 50-54.

Msibi, T. (2013). Queering transformation in higher education. Perspectives in Education, 31(2), 65-73.

Ndhlovu, F., \& Masuku, J. (2004). Mainstreaming African indigenous knowledge systems in higher and tertiary education: The case of Zimbabwe. South African Journal of Higher Education, 18(3), 281288.

Ndlovu-Gatsheni, S. (2013). Decolonizing the university in Africa. The Thinker, 51(2), 46-51.

Neumann, M. (1996). Collecting ourselves at the end of the century. Composing Ethnography: Alternative Forms of Qualitative Writing, 1, 172-198.

Okeke, P. (2003). Higher education for Africa's women: Partners with or cheerleaders for men? In P. Zeleza, P \& A. Olukoshi (Eds.), African universities in the twenty-first century (Vol. 2, pp. 480-492). Codesria.

Otunga, R., \& Ojwang, M. (2003). Women and leadership positions in higher education: A study of Kenyan universities. In P. Zeleza \& A. Olukoshi (Eds.), African universities in the twenty-first century (Vol. 2, pp. 510-521). Codesria.

Pereira, C. (2007). Gender in the making of the Nigerian university system. Heinemann.

Quijano, A. (2007). Coloniality and modernity/rationality. Cultural Studies, 21(2/3), 168-178.

Santos, B. D. S. (2012). The European university at a crossroads. Idées d'Amériques, 2, 1-9. 
Seidman, S. (2009). Critique of compulsory heterosexuality. Sexuality Research \& Social Policy, 6(1), 18.

Spry, T. (2001). Performing autoethnography: An embodied methodological praxis. Qualitative inquiry, $7(6), 706-732$.

Steyn, M. (2015). Critical diversity literacy: Essentials for the twenty-first century. In S. Vertovec (Ed.), Routledge international handbook of diversity studies (pp. 379-389). Routledge.

Weaving, Rachel V. (2019). Structural adjustment and Zimbabwe's poor. World Bank. http://documents.worldbank.org/curated/en/189141468782142997/Structural-adjustment-andZimbabwes-poor

Zembylas, M., \& Boler, M. (2003). Discomforting truths: The emotional terrain of understanding difference. In P. P. Trifonas (Ed.), Pedagogies of difference (pp. 115-138). Routledge.

Zindi, F. (1994). Sexual harassment in Zimbabwe's institutions of higher education. Zambezia, 21(2), 177-186.

Zvobgo, R. J. (2003). The impact of the economic structural adjustment programme on education in Zimbabwe. The Zimbabwe Bulletin of Teacher Education, 2(2), 65-101. 